\title{
TOTAL AND PERIPHERAL BLOOD FLOW IN ACUTE MYOCARDIAL INFARCTION
}

\author{
BY \\ G. de J. LEE \\ From the Department of Medicine, St. Thomas's Hospital Medical School \\ Received December 17, 1955
}

Acute cardiac infarction is an event that might be expected to produce sudden left ventricular heart failure. Although circulatory collapse is common when myocardial infarction is extensive, the clinical signs of cardiac failure are not often dramatic. Recently, therapy involving intraarterial or intravenous transfusion of patients with severe shock from myocardial infarction has been used (Epstein and Relman, 1949; Silber et al., 1951; Berman and Akman, 1952; Gootnick and Knox, 1953). Similar treatment of patients with acute left ventricular heart failure would be considered foolhardy. The present study of circulatory events occurring in a group of patients admitted to hospital with acute myocardial infarction was an attempt to investigate these apparent discrepancies.

\section{MATERIAL AND Methods}

Eleven patients were studied. All gave a typical history of cardiac infarction occurring within a few hours of admission, and all had electrocardiographic evidence confirming myocardial infarction. On admission, eight of the patients had antero-posterior chest tele-radiograms taken as they lay recumbent upon a stretcher in the casualty department. In six patients these X-rays were subsequently compared with similar films taken after recovery. On admission to the ward, all the patients received $1 / 4$ gr. morphine $\mathrm{HCl}$ intramuscularly. Half an hour later the skin of the antecubital fossa was anæsthetized with 2 per cent xylocaine, and a $1 / 2 \mathrm{~mm}$. polythene catheter inserted through a needle into the antecubital vein; the tip of the catheter was advanced to the superior vena cava and the mean pressure in this region measured, using a saline manometer. At the same time a second needle was inserted into the brachial artery and the blood pressure recorded using a Hansen capacitance manometer (1949). Pressures were measured with reference to the sternal angle. Cardiac output was measured using the Hamilton dye technique, a known volume of dye T1824 being injected via the venous catheter, while rapid small arterial samples were being collected simultaneously (Kopelman and Lee, 1951). The "intrathoracic blood volume" was calculated from the estimated cardiac output and mean dye circulation time. Forearm blood flow was obtained using a venous occlusion plethysmograph filled with water at a temperature of $34^{\circ} \mathrm{C}$.

Two patients subsequently died: one 14 days after admission, from a secondary coronary thrombosis, and one 9 days after admission, from ventricular fibrillation. The remaining nine readily consented to repeat studies being made following recovery some 4-9 weeks after admission. Seven patients, including the two who died, had additional studies performed 1-13 days after admission.

The cardiac output and "intrathoracic blood volume" was compared with similar estimations obtained from a group of normal subjects, a group of patients with left ventricular heart failure, and a third group of patients who had recovered from left ventricular heart failure, studied previously with Dr. H. Kopelman (1951).

\section{RESULTS}

Clinical Findings. The age of the patients varied from 44 to 64 years. Nine were men and two women. 
The clinical findings on admission are shown in Table I and were arbitrarily classified in units: 0 indicated no disability other than pain, while 4 represented severe clinical " shock" manifest by prostration, stupor, a cold sweaty cyanosed skin, and a reduced or imperceptible blood pressure when measured by auscultation.

TABLE I

Clinical State of Patients with Acute Myocardial Infarction on Admission to Hospital

\begin{tabular}{|c|c|c|c|c|c|c|c|c|c|c|}
\hline \multirow{2}{*}{ Patient } & \multirow{2}{*}{ Age } & \multirow{2}{*}{ Sex } & \multirow{2}{*}{ "Shock" } & \multirow{2}{*}{$\begin{array}{l}\text { Mental } \\
\text { state }\end{array}$} & \multirow{2}{*}{$\begin{array}{r}\text { Pain } \\
0-4\end{array}$} & \multicolumn{2}{|c|}{ Skin } & \multirow{2}{*}{$\begin{array}{c}\text { Sweat } \\
0-4\end{array}$} & \multirow{2}{*}{ J.V.P. } & \multirow{2}{*}{$\begin{array}{c}\text { Lung } \\
\text { creps. } \\
0-4\end{array}$} \\
\hline & & & & & & Temp. & Colour & & & \\
\hline $\begin{array}{l}\text { L. N. } \\
\text { J.E. } \\
\text { W. J. } \\
\text { G. C. } \\
\text { R. F. } \\
\text { C. L. } \\
\text { H. W. } \\
\text { W. E. } \\
\text { W. B. } \\
\text { *W. H. } \\
\text { *M. T. }\end{array}$ & $\begin{array}{l}47 \\
61 \\
48 \\
45 \\
45 \\
44 \\
59 \\
64 \\
45 \\
64 \\
57\end{array}$ & $\begin{array}{l}\mathrm{F} \\
\mathrm{M} \\
\mathrm{M} \\
\mathrm{M} \\
\mathrm{M} \\
\mathrm{M} \\
\mathrm{M} \\
\mathrm{M} \\
\mathrm{M} \\
\mathrm{M} \\
\mathrm{F}\end{array}$ & $\begin{array}{l}0 \\
0 \\
1 \\
1 \\
2 \\
2 \\
3 \\
3 \\
3 \\
3 \\
3 \\
4\end{array}$ & $\begin{array}{l}\text { Anxious } \\
\text { Alert } \\
\text { Dull } \\
\text { Anxious } \\
\text { Dull } \\
\text { Anxious } \\
\text { Dull } \\
\text { Dull } \\
\text { Dull } \\
\text { Dull } \\
\text { Semi- } \\
\text { conscious }\end{array}$ & $\begin{array}{l}3 \\
2 \\
3 \\
3 \\
2 \\
3 \\
2 \\
2 \\
1 \\
2 \\
?\end{array}$ & $\begin{array}{l}\text { Warm } \\
\text { Warm } \\
\text { Cool } \\
\text { Cool } \\
\text { Cool } \\
\text { Warm } \\
\text { Cold } \\
\text { Cool } \\
\text { Cold } \\
\text { Cold } \\
\text { Cold }\end{array}$ & $\begin{array}{l}\text { Pink } \\
\text { Pink } \\
\text { Pale } \\
\text { Pale } \\
\text { Grey } \\
\text { Pale } \\
\text { Grey } \\
\text { Grey } \\
\text { Grey } \\
\text { Grey } \\
\text { Cyanosed }\end{array}$ & $\begin{array}{l}2 \\
0 \\
2 \\
2 \\
2 \\
0 \\
2 \\
3 \\
3 \\
2 \\
3\end{array}$ & $\begin{array}{l}\text { Raised } \\
\text { Raised } \\
\text { Not visible } \\
\text { Raised } \\
\text { Raised } \\
\text { Raised } \\
\text { Raised } \\
\text { Raised } \\
\text { Raised } \\
\text { Raised } \\
\text { Raised }\end{array}$ & $\begin{array}{l}0 \\
0 \\
0 \\
0 \\
1 \\
0 \\
1 \\
1 \\
0 \\
1 \\
1\end{array}$ \\
\hline
\end{tabular}

* W. H. died on the 9th day after admission. M. T. died on the 14th day after admission.

Four patients qualified for Group 3, two for Group 2, two for Group 1, and two for Group 0. The two patients who died were assessed as Group 3 (Case W. H.) and Group 4 (Case M. T.) risks respectively. Pain was present in all cases and its severity varied; it apparently depended to some extent on the level of consciousness of the individual. Only two patients were not sweating at the time of admission. Heart sounds were usually faint and a triple rhythm was heard in six. No pericardial rub was heard on admission, neither did it develop later in any of the patients. The jugular venous pressure was visible above the sternal angle in all patients except one (W. J.). On admission all the patients were able to lie recumbent without respiratory distress, and none complained of dyspnœa. There were isolated scattered crepitations at the lung bases in the Groups $2-4$ patients.

Pulse Rate (Tables II and III, Fig. 1). On admission the pulse rate amongst the eleven patients ranged from 66 to 123 a minute (average 89 a minute). In seven of the nine who recovered, the pulse rate subsequently fell. The pulse rate varied inversely with the stroke volume in eight of the eleven patients studied, but as an isolated observation it gave little information of the clinical severity of the initial illness or of the stroke volume. Thus W. H. and M. T., who were clinically severely shocked on admission and who subsequently died, had pulse rates of 100 and 70 a minute respectively on admission, with stroke volumes of 57 and $71 \mathrm{ml}$. at that time. In contrast, L. N. and W. J., with no clinical signs of circulatory distress and pulse rates of 108 and 90 a minute on admission, had stroke volumes of 103 and $98 \mathrm{ml}$. respectively.

Blood Pressure (Tables II and III, Fig. 1). The mean blood pressure measured intra-arterially on admission ranged from 78 to $113 \mathrm{~mm}$. $\mathrm{Hg}$ (average $98 \mathrm{~mm}$. Hg). No obvious correlation existed between the mean blood pressure at the onset of the illness and the clinical severity of symptoms or the initial cardiac output. Amongst the nine patients who were studied again after recovery, four showed a rise in mean pressure associated with a rise in stroke volume. Three of these patients' pressures rose to hypertensive levels. The remaining five also showed a rise in stroke volume with recovery; this was associated with a fall in mean pressure. The initial clinical state of these patients was less shocked than was the state of the four patients whose mean pressure rose with recovery.

Pulse pressure on admission varied between 35 and $70 \mathrm{~mm}$. $\mathrm{Hg}$ (average $50 \mathrm{~mm}$. Hg). In six patients the pulse pressure increased following recovery and in three patients the pulse pressure decreased with recovery.

The initial mean pressures of the two patients who subsequently died (W. H. and M. T.) were 111 and $87 \mathrm{~mm}$. respectively; the pulse pressures were 54 and $50 \mathrm{~mm}$. $\mathrm{Hg}$ respectively. 


\begin{tabular}{|c|c|c|c|c|c|c|c|c|}
\hline & $\simeq$ & $\stackrel{\bullet}{0} \frac{0}{\pi}$ & 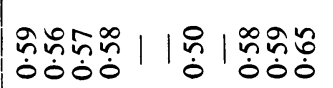 & $\overbrace{0}^{\infty}$ & & $\stackrel{\infty}{\sim}$ & $\stackrel{H}{U} \cdot \frac{0}{\pi}$ & $\begin{array}{ll}\forall & \ddots \\
0 & 0\end{array}$ \\
\hline & 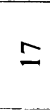 & 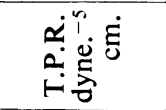 & 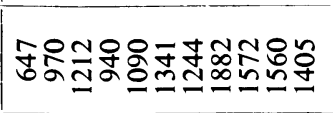 & 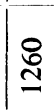 & & $\Xi$ & 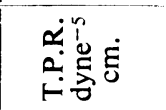 & 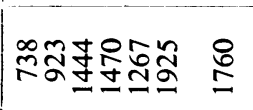 \\
\hline & $\underline{-}$ & 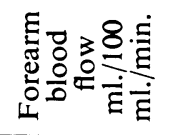 & 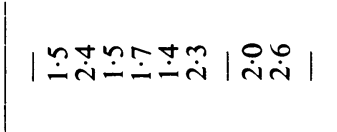 & $\stackrel{9}{\dot{q}}$ & & $\because$ & 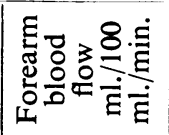 & 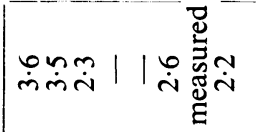 \\
\hline & $\cong$ & 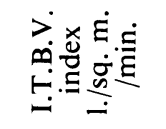 & 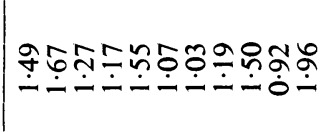 & $\stackrel{\dddot{m}}{\dot{m}}$ & & $\simeq$ & 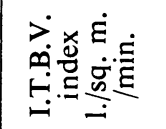 & 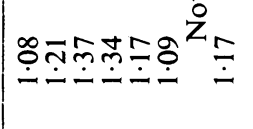 \\
\hline z & \pm & 我象象 & $\dot{\dot{\sim}} \dot{m} \dot{\sim} \dot{\sim} \dot{\sim} \dot{\sim} \dot{\sim} \dot{\sim} \dot{\sim} \dot{\sim} \dot{m}$ & $\ddot{\sim}$ & & $\Xi$ & 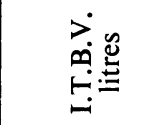 & $\dot{q} \ddot{\sim} \dot{\sim} \dot{\sim} \dot{\sim} \dot{-} \dot{\sim} \dot{-} \dot{-}$ \\
\hline 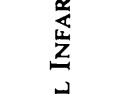 & $m$ & 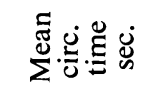 & 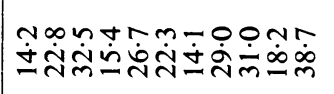 & $\dot{\infty}$ & & 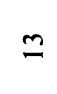 & 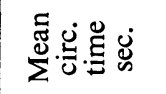 & 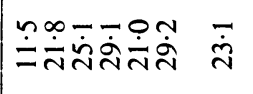 \\
\hline 这 & $\simeq$ & 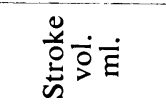 & 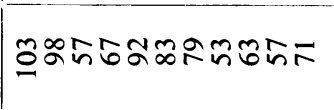 & $\approx$ & & $\simeq$ & 旁宫官 & 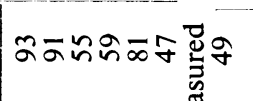 \\
\hline$\sum_{\substack{\omega \\
5}}^{\rightleftarrows}$ & $=$ & 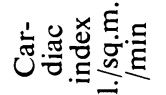 & 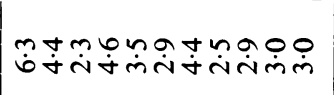 & $\hat{n}$ & & $=$ & 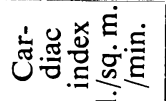 & 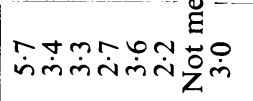 \\
\hline 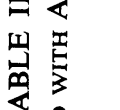 & 으 & 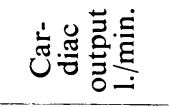 & 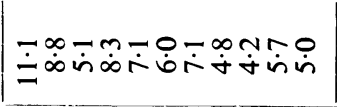 & $\hat{\dot{\theta}}$ & & & 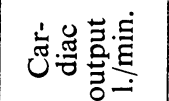 & อ̈̊mmiñ $\dot{\dot{j}}$ \\
\hline 点 & $a$ & 迎 & 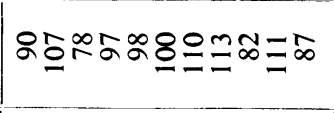 & $\stackrel{2}{a}$ & & $a$ & 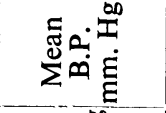 & 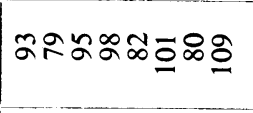 \\
\hline 参 & $\infty$ & 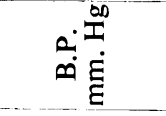 & 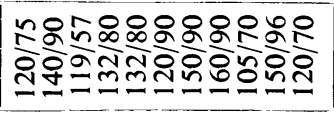 & $\frac{\infty}{\sim}$ & & $\infty$ & $\begin{array}{l}0.00 \\
\dot{\infty}: \dot{E} \\
\dot{E}\end{array}$ & 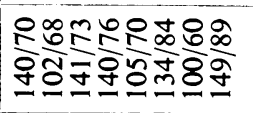 \\
\hline 茎 & r & 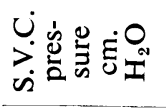 & 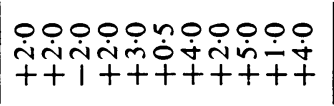 & $\dot{\tilde{\tau}}$ & & $r$ & 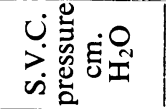 & 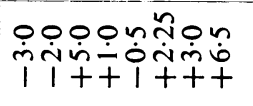 \\
\hline $\begin{array}{l}z \\
\vdots \\
\vdots \\
5\end{array}$ & 6 & 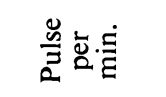 & 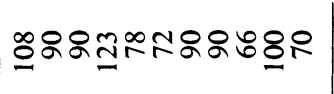 & $\infty$ & & 6 & 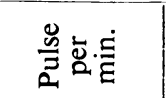 & 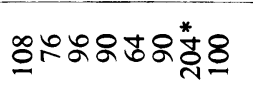 \\
\hline 㞻 & $n$ & 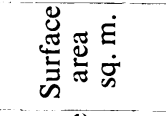 & 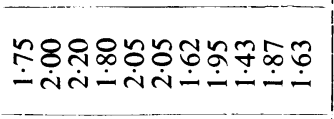 & $\stackrel{\infty}{-}$ & & $n$ & 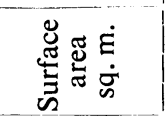 & \\
\hline & $\theta$ & $\stackrel{\infty}{<}$ & 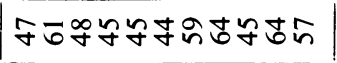 & $n$ & & $\nabla$ & $\stackrel{8}{<}$ & \\
\hline & $m$ & 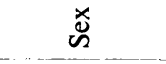 & $山 \Sigma \Sigma \Sigma \Sigma \Sigma \Sigma \Sigma \Sigma \Sigma \Sigma 山$ & & & $m$ & $\stackrel{\times}{\varpi}$ & \\
\hline$\sum_{\substack{0\\
}}^{0}$ & $N$ & 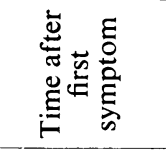 & 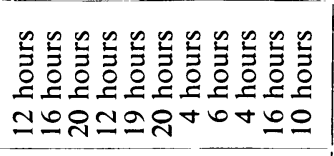 & $\begin{array}{l}\dot{0} \\
\stackrel{\Xi}{0} \\
\stackrel{1}{0} \\
\dot{\simeq}\end{array}$ & 点 & $\sim$ & 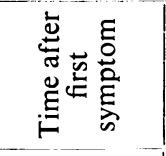 & 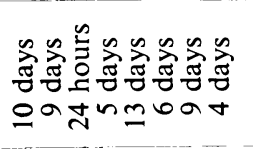 \\
\hline $\begin{array}{l}z \\
z \\
\ddot{z}\end{array}$ & - & $\stackrel{\vec{E}}{\stackrel{\vec{E}}{\vec{E}}}$ & 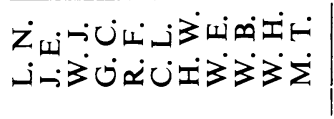 & 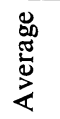 & $\begin{array}{l}\mathfrak{m}_{\tilde{\omega}} \\
\ddot{n} \\
\ddot{n}\end{array}$ & - & $\stackrel{\vec{E}}{\stackrel{\vec{E}}{\pi}}$ & 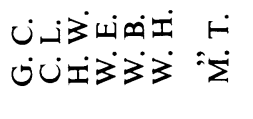 \\
\hline
\end{tabular}




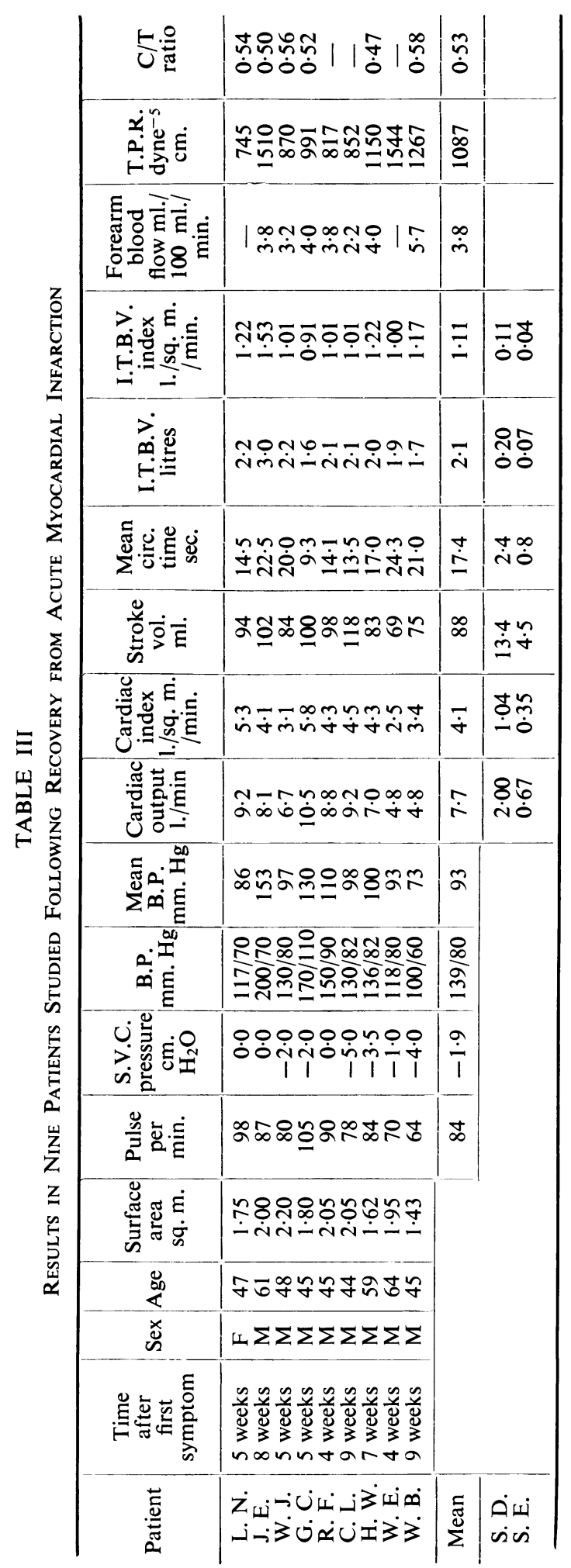




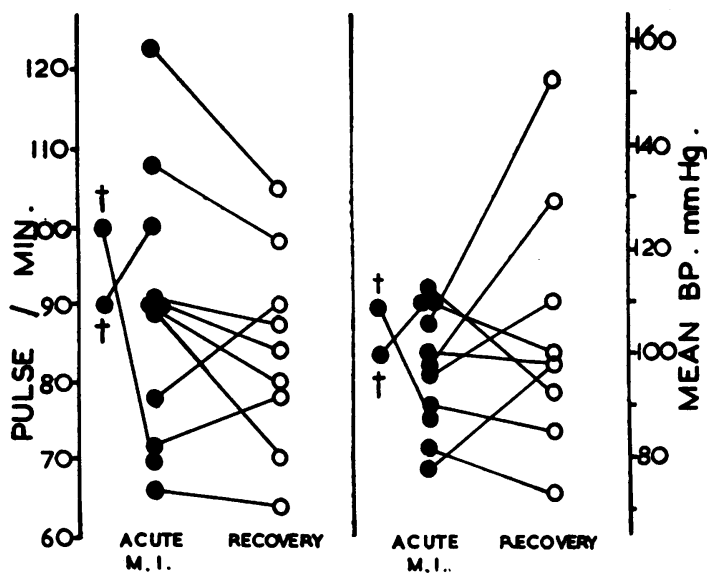

FIG. 1.-The pulse rate per minute, and mean blood pressure in $\mathrm{mm}$. Hg following acute myocardial infarction, and after recovery. In this and subsequent figures, crosses indicate that the relevant patient died subsequently.
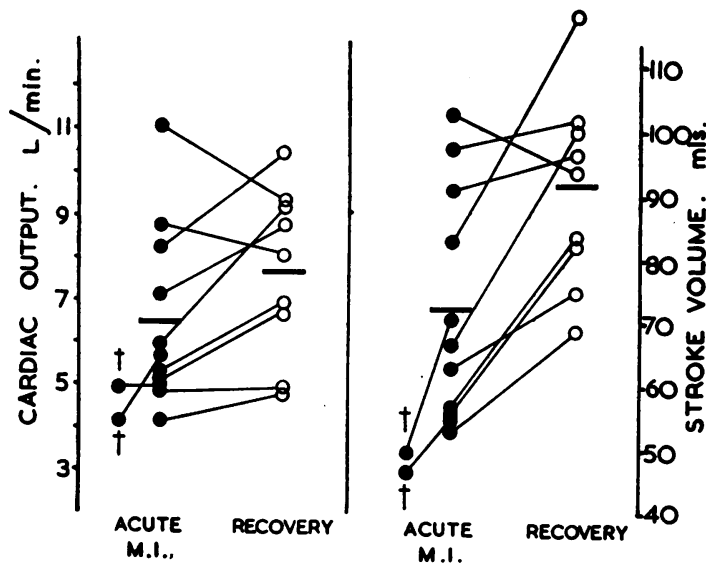

Fig. 2.-Cardiac output (1./min.) and stroke volume (ml.) following acute myocardial infarction and after recovery. In this and subsequent figures the thick horizontal lines, where present, indicate average figures for the appropriate group.

Cardiac Output (Tables II and III, Fig. 2). The initial minute cardiac output ranged between 4.2 and $11.1 \mathrm{l} . / \mathrm{min}$. (average $6.7 \mathrm{l} . / \mathrm{min}$.) and correlated with the clinical severity of the illness, being lower the severer the degree of circulatory collapse. Thus W. H. and M. T., who were admitted semi-conscious and collapsed, had a cardiac output of $5.71 . / \mathrm{min}$. and $5.01 . / \mathrm{min}$. respectively, while L. N. and J. E. who had few symptoms other than pain, had a cardiac output that was actually raised initially, being $11 \cdot 11 . / \mathrm{min}$. and 8.81 . $/ \mathrm{min}$. respectively. In both the latter patients the cardiac output fell with recovery to $9.21 . / \mathrm{min}$. and $8 \cdot 1 \mathrm{l} . / \mathrm{min}$. respectively.

The minute cardiac output rose following recovery in six of the remaining seven surviving patients, the seventh showing no change in cardiac output. (Average cardiac output on recovery was $7.71 . / \mathrm{min}$.) When expressed as stroke volume, all the patients except $\mathrm{L}$. N. showed a ise in stroke output following recovery (average on admission $75 \mathrm{ml}$. per beat; average following recovery $88 \mathrm{ml}$. per beat). Case $\mathrm{L}$. N. was a woman whose only symptom was pain and who was extremely alarmed by her symptoms. Her initial stroke output was raised (103 ml.); it fell towards normal after recovery (94 ml.). Cases W. H. and M. T., who were severely collapsed when initially studied and died nine and fourteen days later respectively, had initial stroke volumes of $57 \mathrm{ml}$. and $71 \mathrm{ml}$. respectively. W. H. when studied six days later showed a fall in cardiac output from $5.71 . / \mathrm{min}$. to 4.21 ./min., the stroke volume falling to $47 \mathrm{ml}$./beat. M. T., studied again three days after admission, showed a cardiac output of $4.91 . / \mathrm{min}$. at the expense of a fall in stroke volume from 71 to $49 \mathrm{ml}$./beat.

The reduction in cardiac output following acute myocardial infarction was compared with that occurring in a group of thirteen patients with left ventricular heart failure previously studied with Dr. H. Kopelman (Fig. 3). The two groups were not strictly comparable as the range of disability amongst the group with acute myocardial infarction was wide and the number studied too small to merit statistical analysis. However, in no instance was the reduction in cardiac output amongst the patients with acute myocardial infarction as great as that obtained in the group with left ventricular heart failure. The cardiac index ranged from 2.5 to 6.31 ./sq. m./min. (average $3.71 . / \mathrm{sq} . \mathrm{m} . / \mathrm{min}$.) amongst the eleven patients studied with acute myocardial infarction: among the group with left ventricular heart failure the mean cardiac index was $1.951 . / \mathrm{sq} . \mathrm{m} . / \mathrm{min} . \pm 0 \cdot 121$. The reduction in cardiac output still present in a second group of sixteen patients studied following recovery from left ventricular heart failure also tended to be greater than that obtained in the group studied following acute myocardial infarction, being $2.61 . / \mathrm{sq} . \mathrm{m} . / \mathrm{min} . \pm 0 \cdot 11 \mathrm{l}$. In the group of nine patients studied following recovery from acute myocardial infarction, cardiac output had risen to a range identical with that obtained from a group of ten normal subjects previously studied with Dr. Kopelman. (Following recovery from infarction: $4.11 . / \mathrm{sq} . \mathrm{m} . / \mathrm{min} . \pm 0.91 \mathrm{l}$; normal group: 4.1 1./sq. m./min. $\pm 0 \cdot 35$ l.)

Superior Vena Caval Pressure (Tables II and III, Fig. 4). In every case except one (W. J.) the jugular venous pressure was raised clinically on admission. All nine patients who recovered showed a fall in 


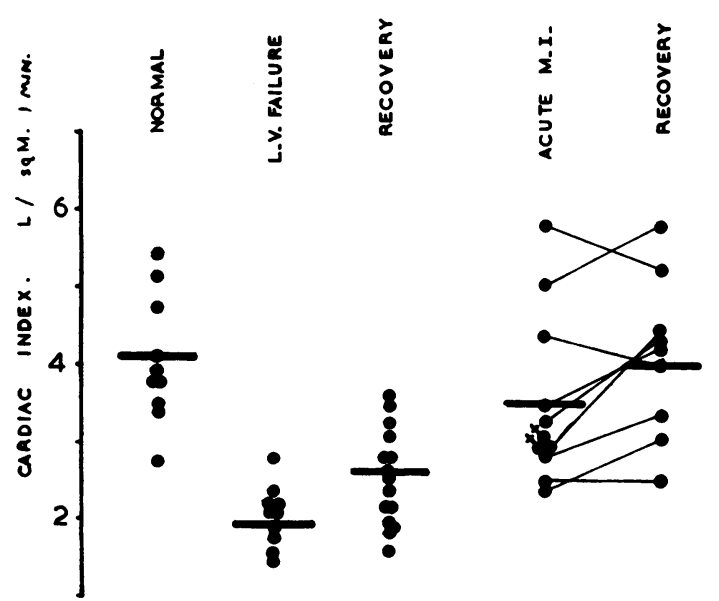

FIG. 3.-Comparison of cardiac indices (1./sq. metre/ min.) between groups of (a) Controls, (b) left ventricular failure, (c) recovered from left ventricular failure, (d) acute myocardial infarction, (e) recovered from acute myocardial infarction.

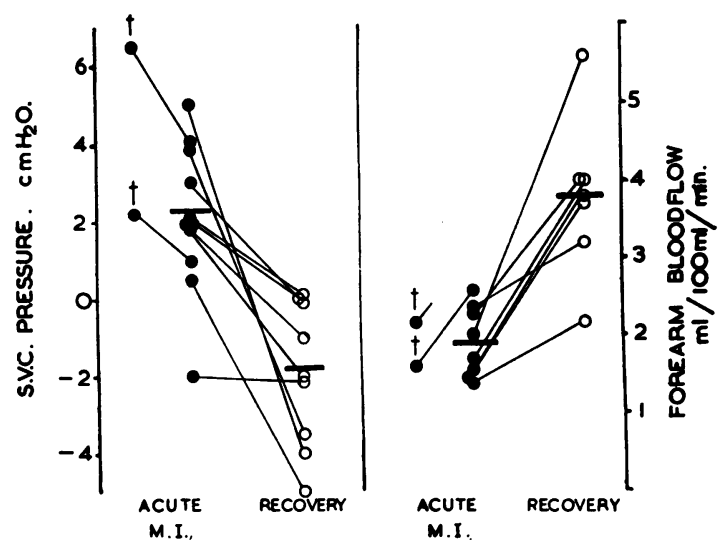

FIG. 4.-Superior vena caval pressure $\left(\mathrm{cm} . \mathrm{H}_{2} \mathrm{O}\right.$ from sternal angle) and forearm blood flow (ml./100 $\mathrm{ml}$. forearm $/ \mathrm{min}$.) in acute myocardial infarction and following recovery.

superior vena caval pressure ranging from 2 to $9 \mathrm{~cm}$. $\mathrm{H}_{2} \mathrm{O}$ (average $4 \cdot 2 \mathrm{~cm} . \mathrm{H}_{2} \mathrm{O}$ ). In the two patients who subsequently died (W. H. and M. T.) the superior vena caval pressure continued to rise after admission. Figure 5 shows the relationship between cardiac output, expressed as stroke volume, and central venous pressure measured from the superior vena cava. In some patients three separate estimations were made during the period in hospital. In all except one the stroke volume response to an increase in central venous pressure appeared to be decreased during the acute stage of the illness.

Forearm Blood Flow (Tables II and III, Fig. 4). Eight of the eleven patients admitted with acute myocardial infarction had forearm plethysmograph studies performed at the time of initial cardiac output estimation. Forearm blood flow ranged from 1.5 to $2.6 \mathrm{ml} . / 100 \mathrm{ml}$. tissue $/ \mathrm{min}$. (average $1.9 \mathrm{ml} . / 100 \mathrm{ml}$. tissue/min.). Seven patients were again studied following recovery; the forearm blood flow had risen in all cases and ranged from 2.2 to $5.7 \mathrm{ml} . / 100 \mathrm{ml}$. tissue $/ \mathrm{min}$. (average $3.8 \mathrm{ml} . / 100 \mathrm{ml}$. tissue $/ \mathrm{min}$.). Cases W. H. and M. T., who were studied at the time of admission but did not survive, showed low forearm blood flows (W. H. $1.6 \mathrm{ml} . / 100 \mathrm{ml}$.; M. T. $2 \cdot 2 \mathrm{ml} . / 100 \mathrm{ml}$. tissue/min.).

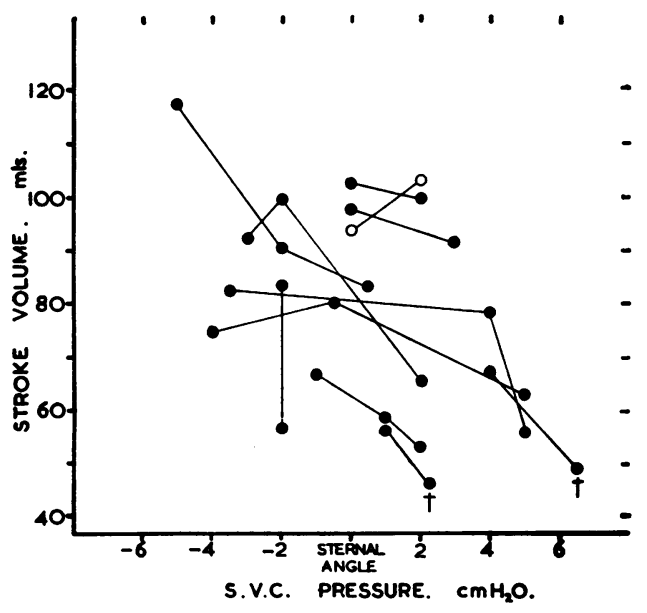

FIG. 5.-Relationship between stroke volume and superior vena caval pressure. Open circles represent Case L. N. (see Discussion).

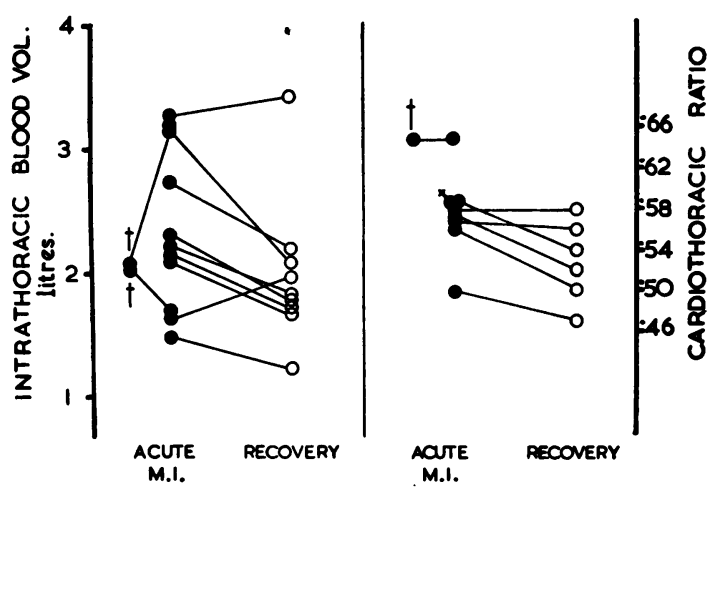

Fig. 6.-The intrathoracic blood volume (litres) and cardiothoracic ratio in acute myocardial infarction and following recovery. 
Total Peripheral Resistance (Tables II and III).

$$
\text { T.P.R. }\left[\frac{\text { Mean B.A. pressure -S.V.C. pressure }(\mathrm{mm} . \mathrm{Hg})}{\text { Stroke volume (ml.) }}\right] \times 1332 \text { dyne } \mathrm{cm} .^{-5}
$$

Calculated total peripheral resistance on admission varied between 647 and 1882 (average 1260) dyne cm. ${ }^{-5}$. The peripheral resistance was highest in the most collapsed cases and continued to rise in the two patients who died. It fell in six of the nine patients who were studied again following recovery, being 745-1510 (average 1084) dyne $\mathrm{cm} \cdot .^{-5}$ in this group. Two patients showed a rise in peripheral resistance following recovery (L. N. and J. E.); both these patients had a raised cardiac output on admission. One patient (G. C.) showed no significant change in peripheral resistance.

Intrathoracic Blood Volume (Tables II, III, Fig. 6 and 7). The circulating blood volume situated between the point of dye injection into the superior vena cava and the arterial sampling point was calculated

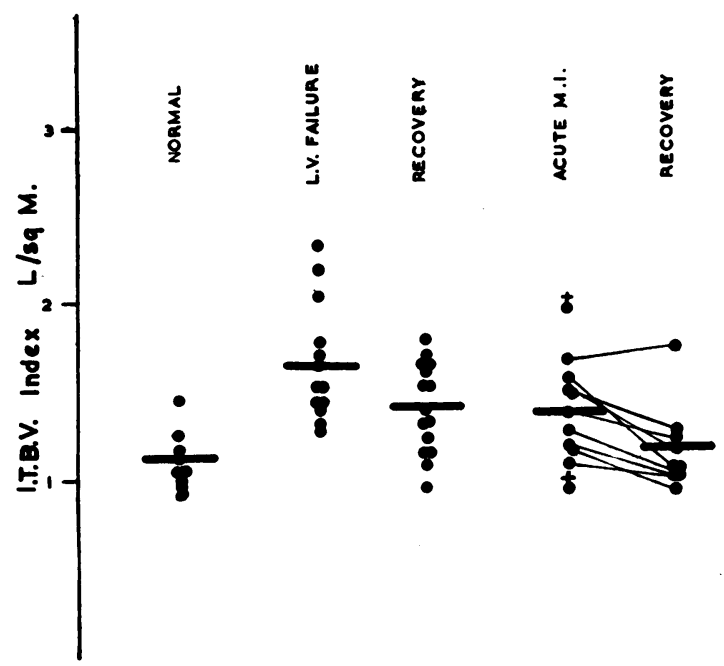

FIG. 7.-Comparison of intrathoracic blood volume indices (1./sq. m.) between groups of (a) Normals, (b) left ventricular heart failure, (c) recovered from left ventricular heart failure, (d) acute myocardial infarction, (e) recovered from acute myocardial infarction.

from the mean dye circulation time between the injection and sampling points, and the cardiac output. This volume was termed the "intrathoracic blood volume." The chief reservoirs composing this volume are the heart chambers and lung vessels. Changes greater than $200 \mathrm{ml}$. are probably significant by this method.

The intrathoracic blood volume index amongst the eleven patients studied with acute myocardial infarction ranged from 0.92 to 1.961 ./sq. m. (average 1.341 ./sq. m.). Though this group is not strictly comparable with a group of ten normal subjects previously studied (Kopelman and Lee, 1951) the intrathoracic blood volume was greater than in the normal group where the volume was $1 \cdot 141 . / \mathrm{sq} . \mathrm{m} . \pm 0.061$. Following recovery, the intrathoracic blood volume fell towards normal values-ranging from 0.91 to $1.531 . / \mathrm{sq}$. $\mathrm{m}$. (mean $1 \cdot 11$ 1./sq. m. $\pm 0 \cdot 04$ ).

The intrathoracic blood volume during the acute phase of illness was smaller than either the group of patients studied with left ventricular heart failure $(1 \cdot 68 \mathrm{l}$./sq. m. $\pm 0 \cdot 101$.) or the group recovered from left ventricular heart failure $(1.41$ l./sq. m. \pm 0.071 . $)$.

Heart Size (Tables II and III, Fig. 6). Accurate heart size measurement by simultaneous P.A. and lateral tele-radiograms were not undertaken, but the A.P. cardio-thoracic ratio was measured as a rough indication of heart size changes in eight patients. Meneely and Chesnut (1947) took a ratio of 0.54 as the upper limit of normal. In eight patients with acute myocardial infarction initial C.T. ratios ranged from 0.50 to $0 \cdot 65$. There was a slight fall in this ratio in six patients who were $\mathrm{X}$-rayed again 
following recovery $(0 \cdot 47-0.58)$. Patients W. H. and M. T., who subsequently died, had initial C.T. ratios of 0.59 and 0.65 respectively.

\section{Discussion}

The most consistent finding in the present study of acute myocardial infarction was an initially raised central venous pressure. This was clinically visible in the neck in all but one patient, and occurred whether or not there were clinical signs of shock. This clinical sign has been confirmed in a large number of similar patients examined since this study was completed. A typical history associated with a raised central venous pressure would appear to be as reliable for diagnosis as an abnormal cardiogram. This opinion differs from previous authors, who also reported a raised central venous pressure in acute myocardial infarction, but only when shock or cardiac failure was manifest (Fishberg et al., 1934; Stead and Ebert, 1942; Freis et al., 1952; Gilbert et al., 1954; Smith et al., 1954).

The present study only partly confirms previous workers' findings that the cardiac output is reduced in acute myocardial infarction, and that it is progressively lowered the severer the degree of shock (Grishman and Master, 1941; Hauss and Koppermann, 1950; Pritchard and Hellerstein, 1950; Freis et al., 1952; Gilbert et al., 1954; Smith et al., 1954.) Amongst the eleven patients studied, two (L. H. and J. E.) with uncomplicated myocardial infarction, whose only apparent disability was pain, had initially raised cardiac outputs which fell following recovery: both had a raised central venous pressure. Calculated total peripheral resistance in both cases was low, initially suggesting vasodilatation, although forearm blood flow in J. E. was also reduced at that time. Both patients were extremely alarmed by their symptoms and possibly this type of cardiac response is explicable by a release of adrenalin acting upon a still responsive myocardium.

Among even the most severely collapsed patients cardiac output was surprisingly well maintained. The lowest cardiac output was $4 \cdot 21 . / \mathrm{min}$. $(2 \cdot 21 . / \mathrm{sq} . \mathrm{m} . / \mathrm{min}$.) from W. H. three days before his death from sudden ventricular fibrillation. Freis et al. (1952) and Smith et al. (1954) both report average cardiac indices from groups of patients with cardiogenic shock well below this figure; while the mean cardiac output in a group of patients studied with left ventricular failure, and quoted in the present report, was also slightly lower $(1.951 . / \mathrm{sq} . \mathrm{m} . / \mathrm{min}$.). However, it is possible that the present study was made on selected cases in that the most severely affected may have died before reaching hospital. But even M. T. and W. H., who were both admitted collapsed and who subsequently died, were able to maintain a reasonable cardiac output. Fig. 8 shows transverse sections of the ventricles of these two patients and reveals that in both cases half the circumference of the left ventricle contained recently infarcted tissue. In spite of this, W. H.'s cardiac output on admission was 5.71 ./min. (57 ml. per stroke), while M. T. had an initial cardiac output of $5.01 . / \mathrm{min}$. $(71 \mathrm{ml}$. per stroke). However, Fig. 2 shows that the maintenance of minute cardiac output occurred at the expense of decreased stroke volume, which tended to be lowest in the most severely shocked patients and continued to fall as their condition deteriorated.

Evidence that the left ventricular response to changes in filling pressure had altered following acute myocardial infarction is only presumptive from the present data, because the assumption must be made that measured pressure changes in the superior vena cava reflect similar unmeasured changes in the left atrium. Such an assumption seems not unreasonable for Case et al. (1954) have shown in the dog that the left atrial pressure rises following myocardial ischæmia, produced by occlusion of the left main coronary artery. In the same experiments they showed that left ventricular stroke volume and stroke work progressively fell as the coronary flow was decreased, and under such circumstances they demonstrated a family of decreasing work response curves as left atrial pressure was increased. Fig. 5 shows that the stroke volume associated with the initial rise in central venous pressure was reduced at some early stage of the acute myocardial infarct in all cases except one, and rose subsequently in those who recovered. The lines connecting the closed circles in the figure serve only to link serial estimations of vena caval pressure and stroke volume during the course of each patient's hospital admission. They do not represent points on 




FIG. 8.-Transverse sections through the ventricles of Case W. H. above (cardiac output 5.7 litres/min.) and Case M. T. below (cardiac output 5.0 litres $/ \mathrm{min}$.). The sections show infarcted tissue, spreading through half the circumference of each left ventricle.

individual falling Starling curves as cursory examination of the figure might suggest, but on the contrary represent single points on a series of changing ventricular response curves (Case et al., 1954) as the function of the myocardium altered during the course of the illness.

Further evidence that the myocardium did not respond normally to changes in venous filling pressure following acute infarction was obtained by use of the Valsalva manœuvre as a test. During the time that the patient's blood pressure was being recorded intra-arterially, he was asked to blow a mercury column to a height of $40 \mathrm{~mm}$. $\mathrm{Hg}$ for ten seconds while the effect on the systemic blood pressure was recorded. During this period the raised intrathoracic pressure impairs systemic venous return to the heart and the central effective venous pressure falls (Lee et al., 1954). In normal subjects this decreases stroke output and pulse pressure with consequent systemic reflex vaso-constriction and rise in diastolic pressure. Persistence of this vaso-constriction is largely responsible for the subsequent " overshoot" in blood pressure that follows the Valsalva manœuvre. However, in heart failure Sharpey-Schafer (1955) has shown that reduction in cardiac filling pressure 
causes either no change or an increase in pulse pressure, and consequently the arterial pressure record has a square wave pattern with no "overshoot" following the Valsalva manœuvre, because no vaso-constriction has been initiated. Moreover, he has shown that similar changes to those found in heart failure occur initially in acute nephritis (Sharpey-Schafer, 1955), and that subsequent serial pressure records show a progressive return to the normal overshoot as the myocardium regains its normal response to changes in filling pressure.

Very similar changes were found in acute myocardial infarction. The most severely collapsed patient showed an initial heart failure blood pressure response to the Valsalva manœuvres (M. T., Fig. 9a). The response never became normal amongst those who recovered (H. W., Fig. 9b). Patients with intermittent grades of collapse (R. F. and G. C., Fig. 9c and 9d) gave either heart failure or impaired responses to the Valsalva manœuvre, and returned to normal following recovery. Only one patient gave a normal response initially to the Valsalva manœuvre; this was L. N., whose only symptom was severe pain and who also responded normally to a raised central venous pressure by a rise in stroke volume (Fig. 5-open circles).

Thus, in all but the mildest case there was functional evidence of myocardial failure, but in spite of a fall in cardiac output there was sufficient vaso-constriction, indicated by decreased forearm blood flow and increased peripheral resistance, to maintain the blood pressure in the recumbent position. The clinical signs of so-called "shock" therefore appeared to indicate homeostasis rather than circulatory failure. For these reasons it would seem that neither intravenous nor intraarterial transfusion is advisable; and indeed study of previous experience of this form of treatment reveals a depressingly low survival rate and few objective measurements to support any impression of efficiency (Epstein and Relman, 1949; Silber et al., 1951; Berman and Akman, 1952; Gootnick and Knox, 1953). However, suitable pressor amines given with the intent to raise blood pressure, increase coronary blood flow, and yet at the same time produce little change in cardiac output have greater theoretical and practical evidence of their merit (Kurland and Malach, 1952; Hellerstein et al., 1952; Shirley Smith and Guz, 1953). Attempts to raise the oxygen tension in the border areas of infarcted myocardium by increased oxygen diffusion from normally perfused areas have been shown to be partly successful in limiting the size of the infarct. Sayen et al. (1951) accomplished this by raising the arterial oxygen tension in animals with experimentally produced myocardial infarcts by oxygen administration. This would seem useful therapy although Russek et al. (1950) could demonstrate no beneficial changes in the electrocardiogram nor any pain relief among patients with acute myocardial infarction treated with pure oxygen.

Two major paradoxes remain to be discussed. The first is that in spite of evidence of left ventricular failure, clinical signs of pulmonary œedema are absent in all but the most collapsed cases, and the small increase in intrathoracic blood volume that was found could well have been due to change in heart size alone (Fig. 6 and 7). This stimulates speculation regarding the mechanism preventing lung congestion and overt œdema in myocardial infarction. It is suggested that pulmonary capillary pressure probably rarely exceeds the critical level necessary to produce pulmonary œdema, and that this may be accomplished by a "Bernheim" effect resulting from sudden dilatation of the infarcted left ventricle. This would impair right ventricular function and result in some protection of the pulmonary system in spite of a failing left ventricle (Berglund et al., 1955).

The second surprising finding was that neither the degree of systemic vaso-constriction, measured by decrease in forearm blood flow, nor the fall in cardiac output was as great as expected. Brigden and Sharpey-Schafer (1950) have shown that intense systemic vaso-constriction is the rule in left ventricular heart failure and that the forearm blood flow rarely rises above $1.0 \mathrm{ml} . / 100 \mathrm{ml} / \mathrm{min}$. Acute coronary occlusion differs from other causes of heart failure in producing sudden injury and death of myocardium. This may well be accompanied by release of vasodilator substance from the infarcted area, or by reflex vasodilatation. For instance, the Bezold reflex initiates bradycardia and systemic vasodilatation when afferent fibres from the ventricles are stimulated by chemical injury or pressure increase (Dawes, 1947; Jarisch and Zotterman, 1949; Dawes et al., 

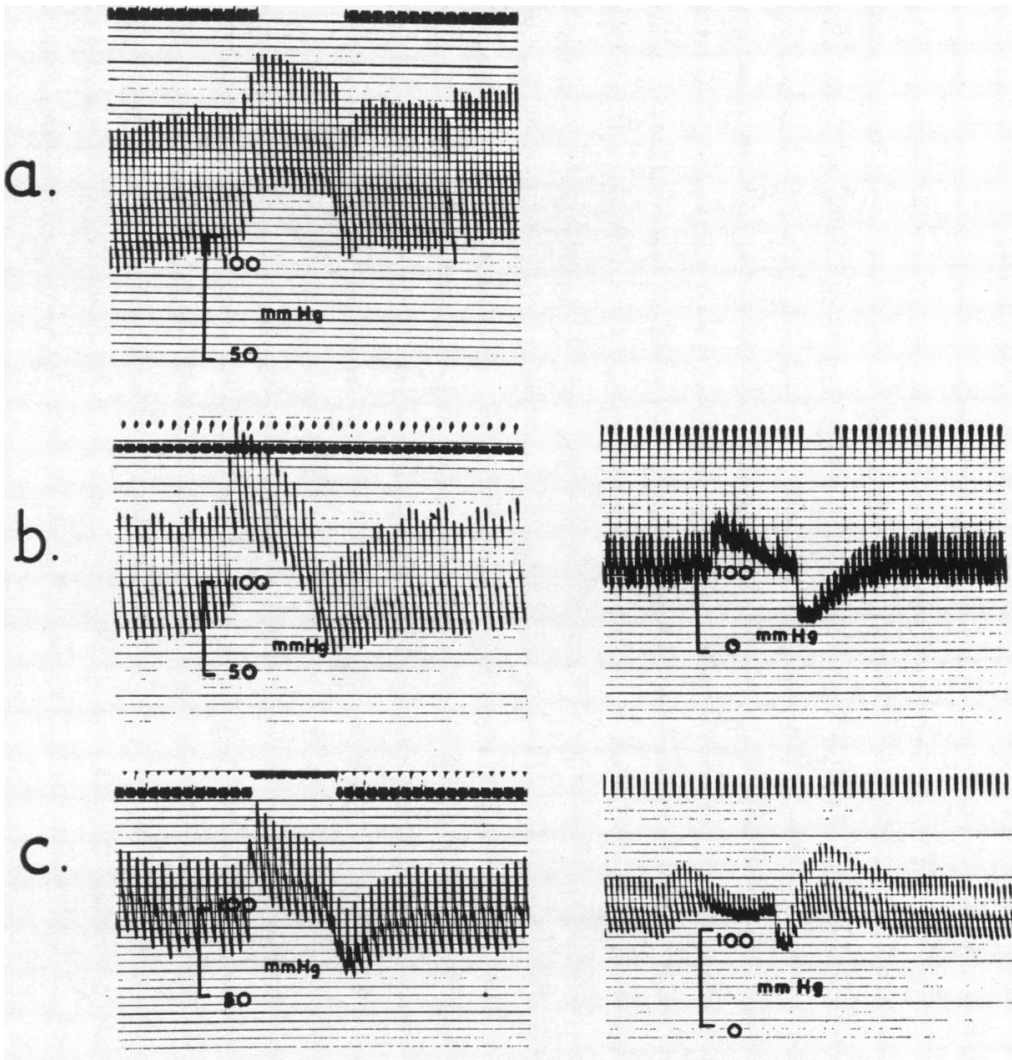

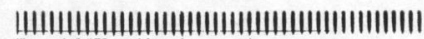
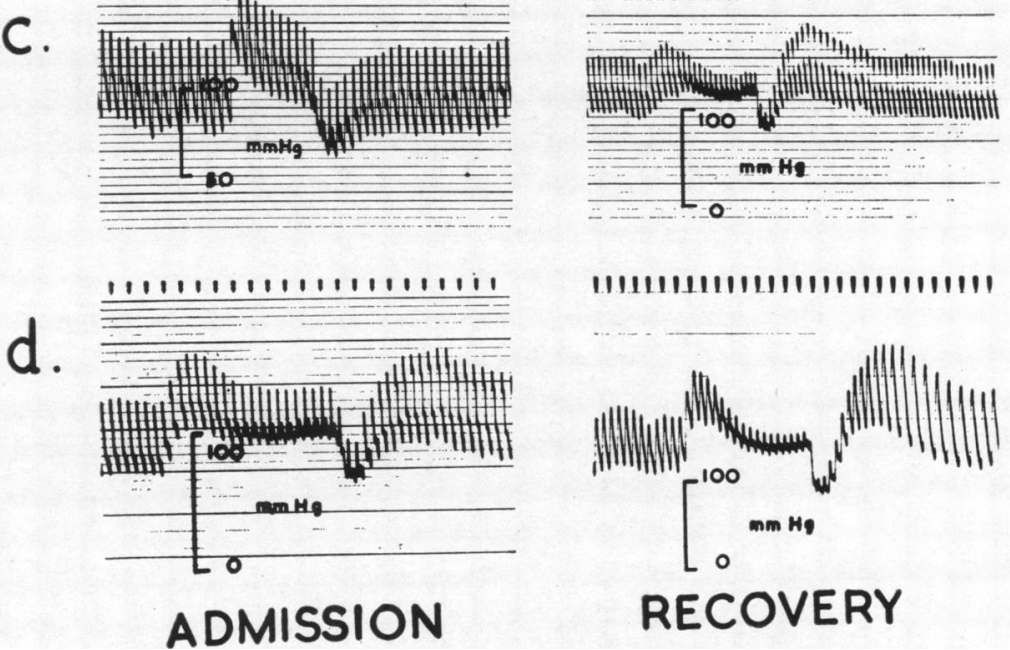

Fig. 9.-The blood pressure responses to Valsalva's manœuvre in patients with acute myocardial infarction and following recovery. Time marker shown recording seconds.

(a) Case M. T.: initial heart failure response; subsequently died.

(b) Case H. W.: modified heart failure response which did not become normal following recovery.

(c) Case R. F.: modified heart failure response; normal response following recovery.

(d) Case G. C.: Almost normal initial response, becoming completely normal following recovery.

1951). Afferent stimulation from the infarcted or neighbouring ischæmic areas might similarly cause vasodilatation and tend to counteract vasoconstriction initiated by the decrease in stroke volume that follows myocardial infarction. 


\section{SUMMARY}

Eleven patients admitted to hospital following acute myocardial infarction have been studied. In nine, further studies were performed following recovery. Two patients died.

Pulse and blood pressure measurements alone were unhelpful in assessing clinical severity, and signs of pulmonary congestion were minimal.

The central venous pressure was raised in all but one patient. Cardiac output was reduced in all but two patients, and was lowest in those clinically most collapsed. It returned to normal following recovery. It was not as greatly reduced in myocardial infarction as in a group of patients with left ventricular heart failure. Forearm blood flow was reduced to approximately half normal, and rose following recovery. Intrathoracic blood volume was slightly increased and returned to normal limits following recovery. There was also a slight increase in heart size.

I am most grateful to Dr. R. Hilton, Dr. H. K. Goadby, Dr. J. B. Harman, and Dr. J. S. Richardson for permission to study the patients under their care. I wish to thank Dr. B. E. Miles, Dr. H. B. Kelly, and Dr. P. Handforth for assistance at the bedside, and am grateful to Mr. M. E. Dunn for his technical help.

\section{REFERENCES}

Berman, E. F., and Akman, L. C. (1952). Amer. Heart J., 43, 264.

Berglund, E., Sarnoff, S. J., and Isaacs, J. P. (1955). Circulation Res., 3, 133.

Brigden, W., and Sharpey-Schafer, E. P. (1950). Clin. Sci., 9, 93.

Case, R. B., Berglund, E., and Sarnoff, S. J. (1954). Circulation Res., 2, 319.

Dawes, G. S. (1947). J. Pharmacol. Exper. Therap., 89, 325.

- Mott, J. C., and Widdicombe, J. G. (1951). J. Physiol., 115, 258.

Epstein, J. A., and Relman, A. S. (1949). New Engl. J. Med., 241, 889.

Fishberg, A. M., Hitzig, W. M., and King, F. H. (1934). Arch. intern. Med., 54, 997.

Freis, E. D., Schnaper, H. W., Johnson, R. L., and Schreiner, G. E. (1952). J. clin. Invest., 31, 131.

Gilbert, R. P., Goldberg, M., and Griffin, J. (1954). Circulation, 9, 847.

Gootnick, A., and Knox, F. H., Jr. (1953). Circulation, 7, 511.

Grishman, A., and Master, A. M. (1941). Proc. Soc. Exper. Biol. Med., 48, 207.

Hansen, A. T. (1949). Acta physiol. scand. (Suppl. 68), 19, 1.

Hauss, W. H., and Koppermann, E. (1950). Ztschr. Kreislaufforch, 39, 449.

Hellerstein, H. K., Brofman, B. L., and Caskey, W. H. (1952). Amer. Heart J., 44, 407.

Jarisch, A., and Zotterman, Y. (1949). Acta physiol. scand., 16, 31.

Kopelman, H., and Lee, G. de J. (1951). Clin. Sci., 10, 383.

Kurland, G. S., and Monte Malach (1952). New Engl. J. Med., 247, 383.

Lee, G. de J., Matthews, M. B., and Sharpey-Schafer, E. P. (1954). Brit. Heart J., $16,311$.

Meneely, G. R., and Chesnut, J. L. (1947). Amer. Heart J., 33, 175.

Pritchard, W. H., and Hellerstein, H. K. (1950). J. clin. Invest., 29, 839.

Russek, H. J., Regan, F. D., and Naegele, C. F. (1950). J. Amer. med. Ass., 144, 373.

Sayen, J. J., Sheldon, W. F., Horwitz, O., Kuo, P. T., Pierce, G., Zinsser, H. F., and Mead, J., Jr. (1951). J. clin. Invest., 30, 932.

Sharpey-Schafer, E. P. (1955). Brit. med. J., 1, 693.

(1955). Lancet, 2, 841.

Shirley Smith, K., and Guz, A. (1953). Brit. med. J., 2, 1341.

Silber, E. N., Levin, B. D., and Becker, G. H. (1951). J. Amer. med. Ass., 147, 1626.

Smith, W. W., Wikler, N. S., and Fox, A. C. (1954). Circulation, 9, 352.

Stead, E. A., Jr., and Ebert, R. V. (1942). Arch. intern. Med., 69, 369. 